\title{
Existence and implications of hop-17(21)-enes in the lower Cretaceous of the Saihantala Sag, Erlian Basin, China
}

\author{
Luo Qingyong ${ }^{1}$, Yu Shijun ${ }^{2}$, Liu Yan ${ }^{1}$, Zhang Yanqi ${ }^{1}$, Han Hui ${ }^{1}$, Qi Lin ${ }^{1}$ and \\ Zhong Ningning ${ }^{1 *}$
}

${ }^{1}$ State Key Laboratory of Petroleum Resources and Prospecting, China University of Petroleum, Beijing 102249, China

${ }^{2}$ Jiangxi Division of Geological Prospecting Center, Sinoma, Shang-rao, Jiangxi 334000, China

(C) China University of Petroleum (Beijing) and Springer-Verlag Berlin Heidelberg 2012

\begin{abstract}
C}_{31}$ - to $\mathrm{C}_{35}$-hop-17(21)-enes are identified by gas chromatography-mass spectrometry (GCMS) analysis to exist as double isomers in most samples of the Aershan Formation and members 1 and 2 of the Tenggeer Formation from well SH3. Comprehensive organic geochemistry and organic petrology study indicates that algae and bacteria are the main biological source of lower Cretaceous sediments in the Saihantala Sag, and this is in accordance with the existence of hop-17(21)-enes. The similar distributions of hop-17(21)-enes and hopanes of these samples indicate that hop-17(21)-enes were transformed into hopanes through hydrogenation during diagenesis processes. The existence of hop-17(21)-enes means that not only the formation of organic matter is related to an anoxic environment and a biological source of algae and bacteria, but also hop-17(21)-enes are direct indicators of hydrocarbon rock at an immature to low-maturity stage. High hydrocarbon conversion ratio, algae and bacteria source and a high abundance of organic matter suggest that the Saihantala Sag has the potential to generate immature to low-maturity oil, which may be of great significance for oil exploration in the Erlian Basin.
\end{abstract}

Key words: Biomarkers, hop-17(21)-ene, biological source, immature oil, Erlian Basin

\section{Introduction}

Hopanoids are the most abundant group of complex organic molecules in the geosphere (Ourisson et al, 1984). They are ubiquitous and have a resistant carbon skeleton. For these reasons, hopanoids are widely applied as biomarkers in ancient sediments and oils (Peters and Moldowan, 1993). They have the potential to provide information regarding the original organic matter, maturity, depositional condition and second change. Although extensive research has been conducted on hopanes (Peters and Moldowan, 1993; Moldowan and McCaffrey, 1995; Farrimond and Telnes, 1996), very few studies of hop-17(21)-enes has reported. Currently, agreement has been reached for hop-17(21)-enes on their necessary depositional conditions (hypersaline and anoxic) and maturity significance (immature to low-maturity) (Ten Haven, 1985; Palmer and Zumberge, 1981; Zhao et al, 2003; Zhang and Zhang, 1999). The biological source of hop17(21)-enes may be related to bacteria (Bechtel et al, 2002; 2004; 2007). In our work, the finding of hop-17(21)-enes in well SH3 of the Saihantala Sag provides an opportunity to investigate the geological significance of hop-17(21)-enes,

*Corresponding author. email: nnzhongxp@cup.edu.cn Received July 07, 2011 including their biological source, maturity significance and depositional environments. This paper aims to contribute to the understanding of the geological significance of hop17(21)-enes through comprehensive organic geochemistry and organic petrology.

\section{Geological Setting}

The Erlian Basin, a Mesozoic and Cenozoic faulted basin, developed on the basis of the Hercynian Fold Belt between Inner Mongolia and the Greater Hinggan Mountains, is located in the northeast of the Inner Mongolia Autonomous Region (Zhao et al, 1996). The Erlian Basin underwent the formation of a Mesozoic fold belt, the development of an early-middle Jurassic intermontane basin, a late Jurassic-toearly Cretaceous rift valley, and the late Cretaceous-to-present extinction of the rift valley (Ma, 2005). The Saihantala Sag is located in the Tenggeer depression of the Erlian Basin (Fig. 1). Based on tectonic characteristics, the Saihantala Sag can be divided into five secondary tectonic units: the Sumute hollow belt, the Bayan fault tectonic belt, the Duruji hollow belt, the Chagan slope belt and the Buhe nose-shaped tectonic belt (Fig. 1). Well SH3 is an exploration test well located in the Duruji hollow belt of the Saihantala Sag (Fig. 1). Well SH3 includes Quaternary, Tertiary, lower Cretaceous (the Saihantala 


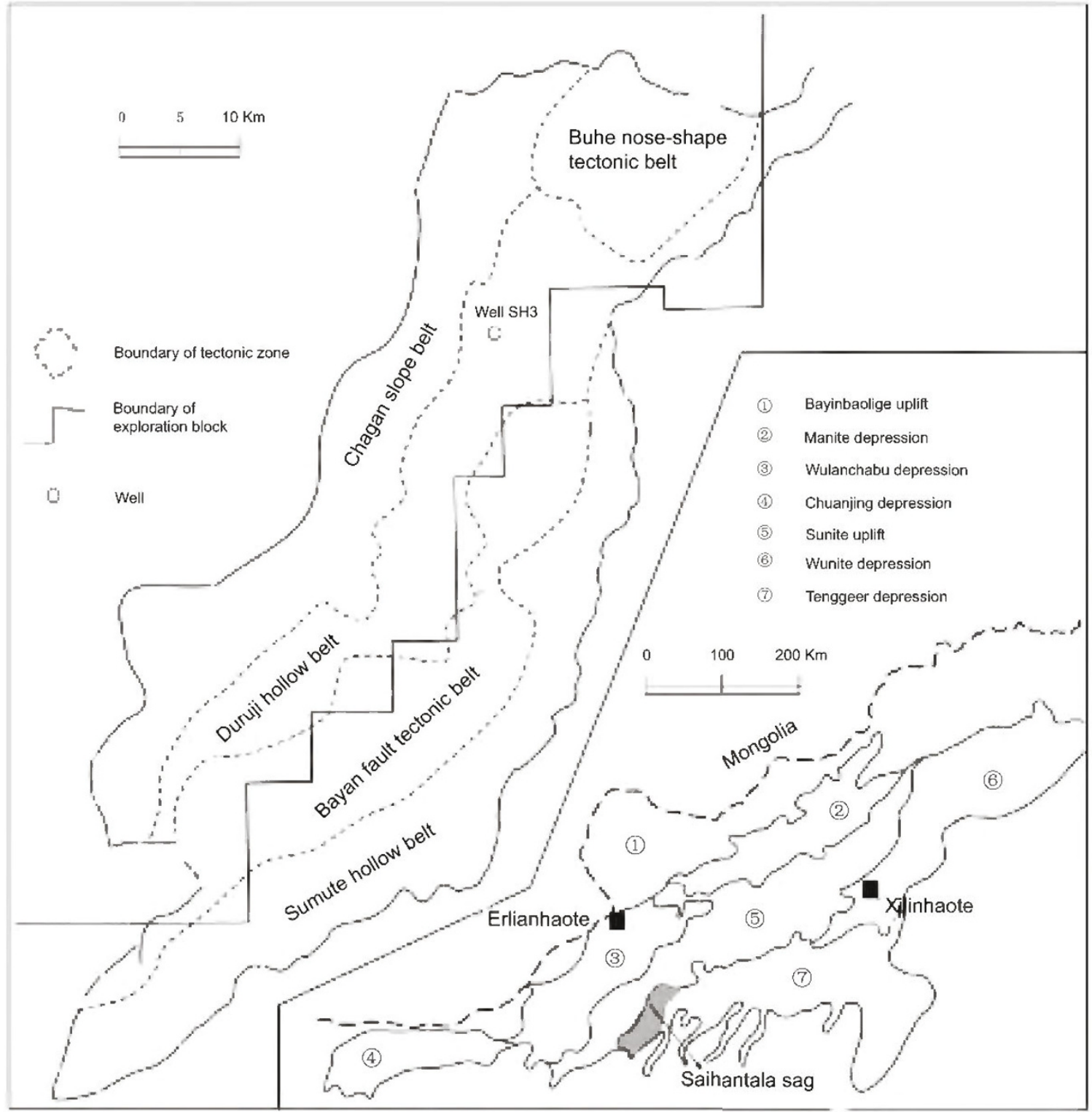

Fig. 1 Tectonic location of well $\mathrm{SH} 3$

Formation, members 1 and 2 of the Tenggeer Formation, and the Aershan Formation) and Paleozoic sediments; the lower Cretaceous is the exploration target. The lower Cretaceous consists of successively developed sediments of deep to semi-deep lakes (Wang et al, 2007). Mudstone is the main sediment in the Aershan Formation and members 1 and 2 of the Tenggeer Formation (Fig. 2).

\section{Samples and methods}

\subsection{Samples}

The samples, which are all mudstones, include 38 rock debris samples and 14 cores from the Aershan Formation and members 1 and 2 of the Tenggeer Formation in well SH3.

\subsection{Methods}

Total organic carbon (TOC) was measured with a Leco CS-230 analyzer (Leco Corporation, USA). Rock pyrolysis measurement was carried out on an OGE-II oil evaluation station (Research Institute of Petroleum Exploration and Development, China). Organic petrology and vitrinite reflectance measurements were made on a UMSP-50 microscopy spectrophotometer (Opton Corporation, Germany).

The GC-MS measurements of saturated hydrocarbons were carried out on an Agilent 6890GC (Agilent Corporation, USA) equipped with an HP-5MS fused silica capillary column $(60 \mathrm{~m} \times 0.25 \mathrm{~mm}$ i.d.; film thickness $0.25 \mu \mathrm{m})$ interfaced to a $5975 \mathrm{i}$ mass spectrometer (electron energy 70 $\mathrm{eV})$. The oven temperature was programmed from $50^{\circ} \mathrm{C}$ (held for 1 minute) to $120^{\circ} \mathrm{C}$ at a rate of $20^{\circ} \mathrm{C} /$ minute and then from 120 to $310^{\circ} \mathrm{C}$ (held at $310^{\circ} \mathrm{C}$ for 25 minutes) at a rate of $3{ }^{\circ} \mathrm{C} /$ minute; Helium was used as the carrier gas, and the data acquisition mode was scan/selected ion monitoring (SCAN/SIM).

Extractable organic matter (EOM) carbon isotopes were analyzed using a Thermofisher Flash 2000EA-Mat253 isotope-ratio mass spectrometer (IRMS) (Thermofisher Corporation, USA). The conditions for the Thermofisher 


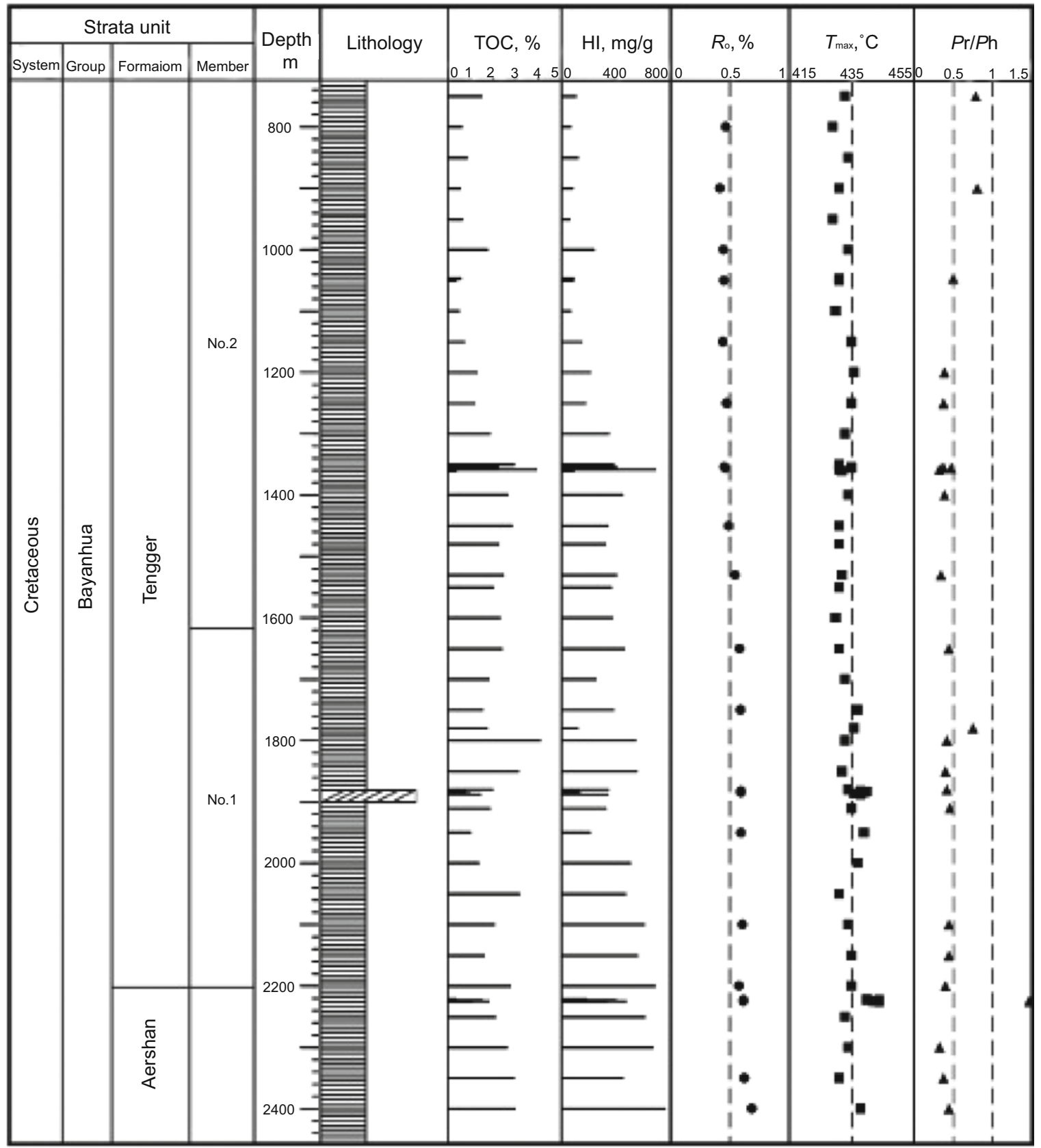

Fig. 2 Geochemical columns of well SH3

Flash 2000EA were: the combustion tube was filled with reduction copper, chromic oxide and silver-containing cobalt oxide; the flow velocity of the carrier gas $\mathrm{He}$ was $100 \mathrm{~mL} /$ minute; the flow velocity of the combustion gas $\mathrm{O}_{2}$ was $250 \mathrm{~mL} /$ minute; the flow velocity of the sweeping gas $\mathrm{He}$ was the same as that of the combustion gas; and the reactor temperature was $980{ }^{\circ} \mathrm{C}$. The pressure was $2 \times 10^{-8}$ mbar. $\delta^{13} \mathrm{C}$ values are expressed relative to Pee Dee Belemnite (PDB) standard.

\section{Results and discussion}

\subsection{Identification of hop-17(21)-enes}

Hop-17(21)-enes, neohop-13(18)-enes, hopanes, morpanes, $17 \beta(\mathrm{H}), 21 \beta(\mathrm{H})$-hopanes and gammacerane were identified in samples from well SH3 by using standards available in software library databases and through comparison with published mass chromatogram data (Schwark et al, 1998) (Fig. 3 and Table 1).

\subsection{Geological significance of hop-17(21)-enes}

4.2.1 Depositional environment significance of hop-17(21)enes

The $\mathrm{C}_{30}$ to $\mathrm{C}_{35}$ series of hop-17(21)-enes and hopanes are identified in most samples from well SH3 (Fig. 3 and Table 1), but no hop-17(21)-enes were found in sample SH3-2225.08. Hopanes exist as $17 \alpha(\mathrm{H}), 21 \beta(\mathrm{H})$ configuration, $17 \beta(\mathrm{H})$, $21 \alpha(\mathrm{H})$ configuration and $17 \beta(\mathrm{H}), 21 \beta(\mathrm{H})$ configuration (Fig. 


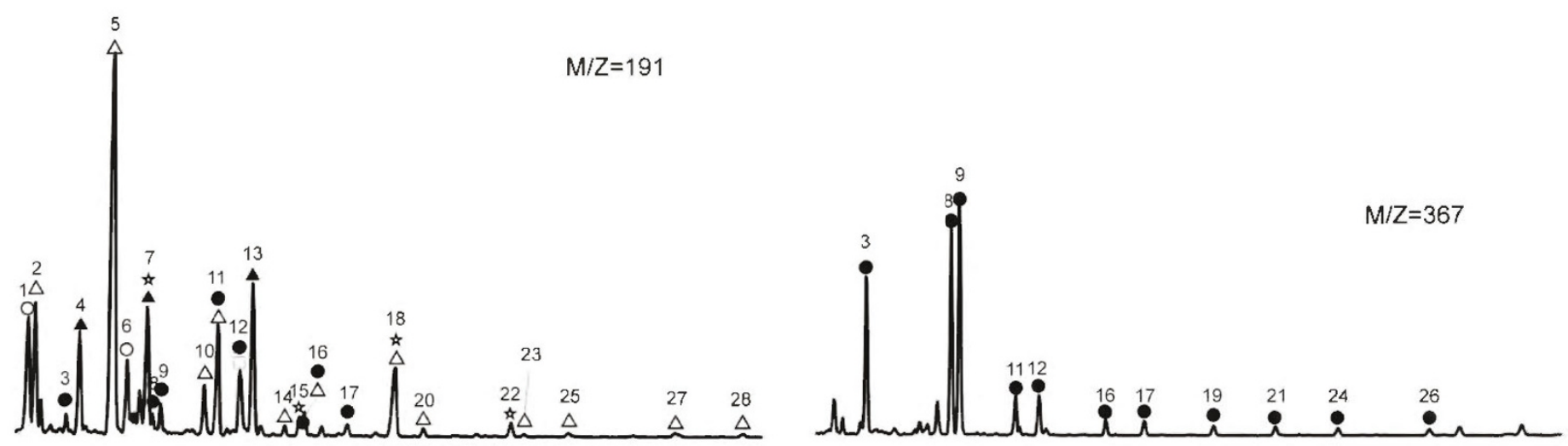

Fig. 3 Mass chromatograms of $M / Z=191$ and $M / Z=367$ for sample SH3-2350 from well SH3

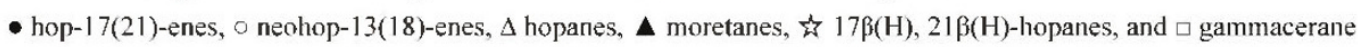

Table 1 Identification results of pentacyclic triterpenoids labeled in Fig. 3

\begin{tabular}{|c|c|c|c|}
\hline Peak & Compound & Peak & Compound \\
\hline l & 30-norneohop-13(18)-ene & 15 & $17 \beta(\mathrm{H}), 21 \beta(\mathrm{H})$-hopane \\
\hline 2 & $17 \alpha, 21 \beta(\mathrm{H})$-30-norhopane & 16 & $\begin{array}{c}17 \alpha, 21 \beta(\mathrm{H}) \text {-Bishomohopane } 22 \mathrm{R}+ \\
\text { Trishomohop-17(21)-ene } 22 \mathrm{~S}\end{array}$ \\
\hline 3 & Hop-13(18)-ene & 17 & Trishomohop-17(21)-ene 22R \\
\hline 4 & $17 \beta, 21 \alpha(\mathrm{H})-30$-norhopane & 18 & $\begin{array}{c}17 \alpha, 21 \beta(\mathrm{H}) \text {-trishomohopane } 22 \mathrm{~S}+ \\
17 \beta(\mathrm{H}), 21 \beta(\mathrm{H}) \text { - homohopane }\end{array}$ \\
\hline 5 & $17 \alpha, 2$ I $\beta(\mathrm{H})$-hopane & 19 & Tetrakishomohop-17(21)-ene $22 \mathrm{~S}$ \\
\hline 6 & Neohop-13(18)-ene & 20 & $17 \alpha, 21 \beta(\mathrm{H})$-trishomohopane $22 \mathrm{R}$ \\
\hline 7 & $\begin{array}{l}17 \beta, 2 \text { l } \alpha(\mathrm{H}) \text {-hopane+ } \\
17 \beta(\mathrm{H}), 21 \beta(\mathrm{H})-30 \text {-norhopane }\end{array}$ & 21 & Tetrakishomohop-17(21)-ene 22R \\
\hline 8 & Hoinohop-17(21)-ene $22 \mathrm{~S}$ & 22 & $17 \beta(\mathrm{H}), 21 \beta(\mathrm{H})$ - Bishomohopane \\
\hline 9 & Homohop-17(21)-ene $22 \mathrm{R}$ & 23 & $17 \alpha, 21 \beta(\mathrm{H})$-tetrakishomohopane $22 \mathrm{~S}$ \\
\hline 10 & $17 \alpha, 21 \beta(\mathrm{H})$-homohopane $22 \mathrm{~S}$ & 24 & Pentakishomohop-17(21)-ene $22 \mathrm{~S}$ \\
\hline 11 & $\begin{array}{l}17 \alpha, 21 \beta(\mathrm{H}) \text {-homohopane } 22 \mathrm{R}+ \\
\text { Bishomohop- } 17(21) \text {-ene } 22 \mathrm{~S}\end{array}$ & 25 & $17 \alpha, 21 \beta(\mathrm{H})$-tetrakishomohopane $22 \mathrm{R}$ \\
\hline 12 & $\begin{array}{l}\text { Gammacerane }+ \\
\text { Bishomohop-17(21)-ene 22R }\end{array}$ & 26 & Pentakishomohop-17(2I)-ene $22 \mathrm{R}$ \\
\hline 13 & $17 \beta, 2 \mathrm{l} \alpha(\mathrm{H})$-homohopane & 27 & $17 \alpha, 21 \beta(\mathrm{H})$-pentakishomohopane $22 \mathrm{~S}$ \\
\hline 14 & $17 \alpha, 21 \beta(\mathrm{H})$-Bishomohopane 22S & 28 & $17 a, 2 \mathrm{I} \beta(\mathrm{H})$-pentakishomohopane $22 \mathrm{R}$ \\
\hline
\end{tabular}

3 and Table 1). Both $\mathrm{C}_{31}$ to $\mathrm{C}_{35} 17 \alpha(\mathrm{H}), 21 \beta(\mathrm{H})$ hopanes and $\mathrm{C}_{31}$ to $\mathrm{C}_{35}$ hop-17(21)-enes exist as doublets of $22 \mathrm{~S}$ and $22 \mathrm{R}$ isomers (Fig. 3 and Table 1). Hop-17(21)-enes were found in most samples of the Aershan Formation, and members 1 and 2 of the Tenggeer Formation from well SH3. Besides the two dominant hopanoid types, neohop- $(13,18)$-ene accompanied by 30 -norneohop-(13,18)-ene are present in most samples (Fig. 3 and Table 1 ).

The distribution of isoprenoid alkane shows that the $\mathrm{Pr} / \mathrm{Ph}$ ratio of sample SH3-2225.08 is much greater than that of other samples (Fig. 2 and Table 2), indicating that sample SH3-2225.08 was deposited under oxic environments, while the other samples were from anoxic depositional conditions. No hop-17(21)-enes were detected in sample SH3-2225.08, and the reason might be that the sample was deposited under an oxic environment. This confirms the possibility of sediments containing hop-17(21)-enes being deposited under an anoxic environment.
Table 2 Detected geochemical parameters of the samples from well SH3

\begin{tabular}{|c|c|c|c|c|c|c|c|}
\hline Sample & Horizon & $\begin{array}{l}\text { Depth } \\
\text { m }\end{array}$ & $\begin{array}{c}\text { TOC } \\
\%\end{array}$ & $\begin{array}{c}\mathrm{HI} \\
\mathrm{mg} / \mathrm{g}\end{array}$ & $\begin{array}{l}R_{\mathrm{v}} \\
\%\end{array}$ & $\begin{array}{c}T_{\max } \\
{ }^{\circ} \mathrm{C}\end{array}$ & $P \mathrm{r} / P \mathrm{~h}$ \\
\hline SH3- 1250 & $\mathrm{~K}_{1} \mathrm{bt}^{2}$ & 1250 & 1.21 & 185 & 0.48 & 435 & 0.38 \\
\hline SH3-1354.8 & $\mathrm{K}_{1} \mathrm{bt}^{2}$ & 1354.8 & 2.25 & 411 & 0.46 & 435 & 0.38 \\
\hline SH3-2100 & $\mathrm{K}_{1} \mathrm{bt}^{\prime}$ & 2100 & 2.07 & 615 & 0.61 & 434 & 0.45 \\
\hline SH3-2200 & $K_{1} b t^{\prime}$ & 2200 & 2.80 & 692 & 0.58 & 435 & 0.40 \\
\hline SH3-2225.08 & $\mathrm{K}_{\mathrm{l}} \mathrm{ba}$ & 2225.08 & 1.86 & 482 & 0.62 & 442 & 1.47 \\
\hline $\mathrm{SH} 3-2350$ & $\mathrm{~K}_{1}$ ba & 2350 & 2.96 & 457 & 0.63 & 431 & 0.38 \\
\hline
\end{tabular}

4.2.2 Biological source and transformation of hop-17(21)-enes

The precursors to hopanes are $\mathrm{C}_{35}$ bacteriohopanepolyols, which are predominantly biosynthesized as membrane constituents of prokaryote (Ourisson et al, 1984). Bottari et al (1972) proposed hop-17(21)-enes for use as a biomarker for fern and moss. While Volkman et al (1986), Wakeham 
(1990) and Bechtel et al $(2002 ; 2004 ; 2007)$ considered that hop-17(21)-enes are directly contributed to sediments by bacteria. Maceral studies have shown that sapropelinites, which are mainly in the shape of line and debris, dominate the maceral. The distribution of amorphous sapropelinites occurs along bedding (Fig. 4) with many mineral-bituminous groundmasses (Fig. 4(a) and (d)). These indicate that the remains of algae underwent microbial degradation during the early diagenesis, some of which formed amorphous sapropelinites and some of which were dispersed to mineral groundmasses forming organic-inorganic complexes, i.e., mineral-bituminous groundmasses. Furthermore, according to geochemical data, the hydrogen index (HI) is high (Fig. 2 and Table 2) and $\delta^{13} \mathrm{C}$ values of EOM are lower than $-28 \%$ (Fig. 5). These indicate that algae and bacteria are the main source of biological material in the lower Cretaceous of the Saihantala Sag. So the likelihood of hop-17(21)-enes coming from bacteria is high.
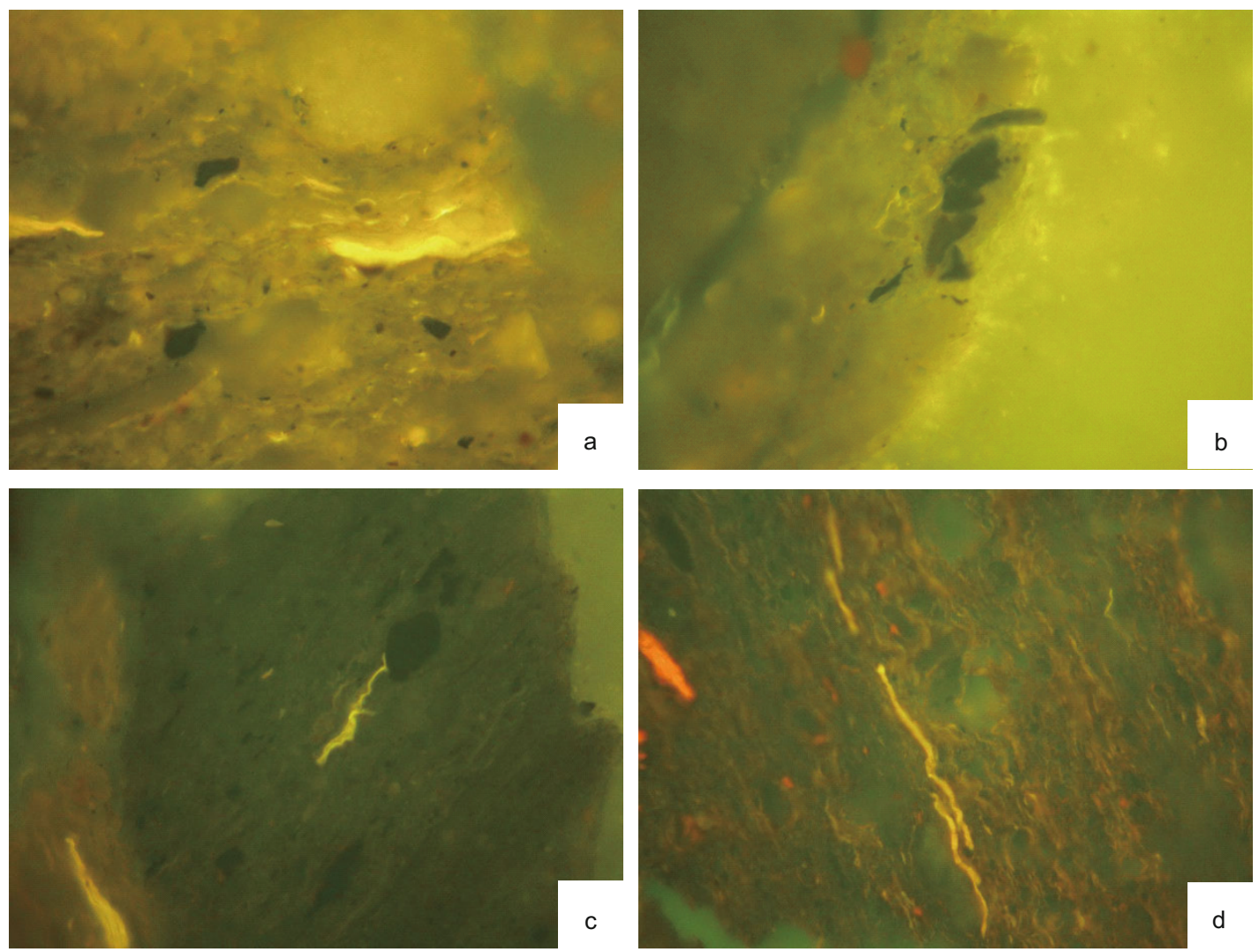

Fig. 4 Photomicrographs of samples from well SH3

(a) Amorphous sapropelinite and mineral-bituminous groundmass, well SH3, $1250 \mathrm{~m}$, member 2 of the Tenggeer Formation, mudstone, fluorescence, $\times 100$; (b) Amorphous sapropelinite and vitrinite, well SH3, $1354.79 \mathrm{~m}$, member 2 of the Tenggeer Formation, mudstone, fluorescence, $\times 100$; (c) Amorphous sapropelinite, well SH3, $1884.59 \mathrm{~m}$, member 1 of the Tenggeer Formation, mudstone, fluorescence, $\times 100$; (d) Amorphous sapropelinite and mineral-bituminous groundmass, well SH3, 2223.08 $\mathrm{m}$, Aershan Formation, mudstone, fluorescence, $\times 100$

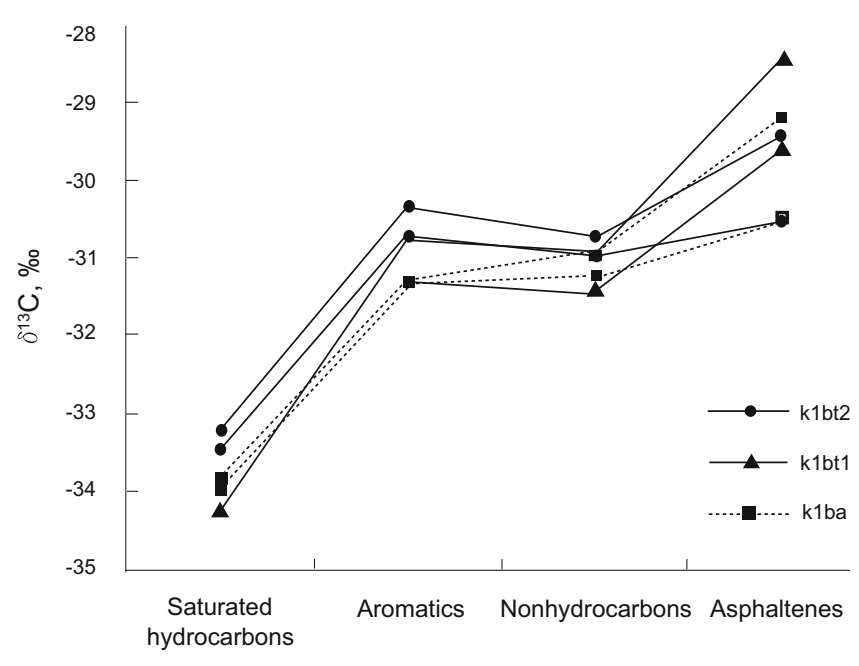

Fig. $5 \mathrm{EOM} \delta^{13} \mathrm{C}$ of the lower Cretaceous source rocks from well $\mathrm{SH} 3$
Samples in the Saihantala Sag reveal an extended hop17(21)-enes distribution with a maximum content of $\mathrm{C}_{31}$ and then smoothly declining to $\mathrm{C}_{35}$, i.e., $\mathrm{C}_{31}>\mathrm{C}_{32}>\mathrm{C}_{33}>\mathrm{C}_{34}>\mathrm{C}_{35}$ (Fig. 3). The distribution of $\mathrm{C}_{31}$ to $\mathrm{C}_{35} 17 \alpha(\mathrm{H}), 21 \beta(\mathrm{H})$ hopanes is the same as that of hop-17(21)-enes. Comparable distributions of $\mathrm{C}_{31}$ to $\mathrm{C}_{35}$ hop-17(21)-enes and hopanes indicate hopanes may have originated from hydrogenation of hop-17(21)-enes.

\subsubsection{Maturity significance of hop-17(21)-enes}

Hop-17(21)-enes are commonly found in modern sediments and low thermal evolution strata. The $\mathrm{C}=\mathrm{C}$ double bond of hop-17(21)-enes is thermally unstable, and hop17(21)-enes are either transformed into stable hopanes or degraded (Ensminger et al, 1977). As a result, hop-17(21)enes were regarded to be the diagnostic biomarker for sediments of an immature to low-maturity stage (Ten Haven et al, 1985; Boon et al, 1983; Kohnen et al, 1991; De las 
Heras et al, 1997). Geochemistry and organic petrology investigations indicate that $R_{\mathrm{o}}$ is lower than $0.7 \%, T_{\max }$ is lower than $455^{\circ} \mathrm{C}$ (Fig. 2 and Tahle 2), and amorphous sapropelinites fluoresce green-yellow to bright-yellow (Fig. 4). These characteristics suggest that the sediments are immature to low-maturity, which confirms the evidence from the existence of unsaturated hop-17(21)-enes and demonstrates the low maturity of the hydrocarbon rock.

\subsection{Potential of generating immature to low-maturity oil from Cretaceons in the Saihantala Sag}

Studies has been reported that lipoids with a high abundance of organic matter and a biological source of algae can generate oil during immature to low-maturity stages (Wang et al, 1995; 1996; Huang et al, 2003). Hydrocarbon rocks in the Saihantala Sag have a high abundance of organic matter (Fig. 2, Table 2) and the main biological source of hydrocarbon rocks are algae and bacteria, a situation which favors the generation of immature oil. A hydrocarbon conversion ratio (i.e. the value of the chloroform hitumen " $\mathrm{A}$ "/ TOC) of $12 \%$ was found at the relatively shallow depth of $1000 \mathrm{~m}$ in members 1 and 2 of the Tenggeer Formation in the Saihantala Sag, and the corresponding $R_{\mathrm{o}}$ is approximately $0.4 \%$ (Fig. 6). However, the hydrocarbon conversion ratio for the deeper sediments of the Aershan Formation reaches 16\%, and the corresponding $R_{\mathrm{o}}$ is approximately $0.7 \%$ (Fig. 6). These indicate immature to low-maturity hydrocarbon rock had generated abundant hydrocarbons. Although immature to low-maturity oil has not yet been found in the Saihantala Sag, the Aershan Formation and members 1 and 2 of the Tenggeer Formation in other sags, such as the Bayindulan Sag (Huang et al, 2003), the Erennaoer Sag, the Jiergalangtu Sag and the Baiyinchagan Sag (Wang et al, 2007), have hosted immature to low-maturity oil. These sags have experienced depositional and tectonic histories similar to the Saihantala Sag. As a result, the Saihantala Sag has the potential to form immature to low-maturity oil, which is important for oil exploration in the Erlian Basin.

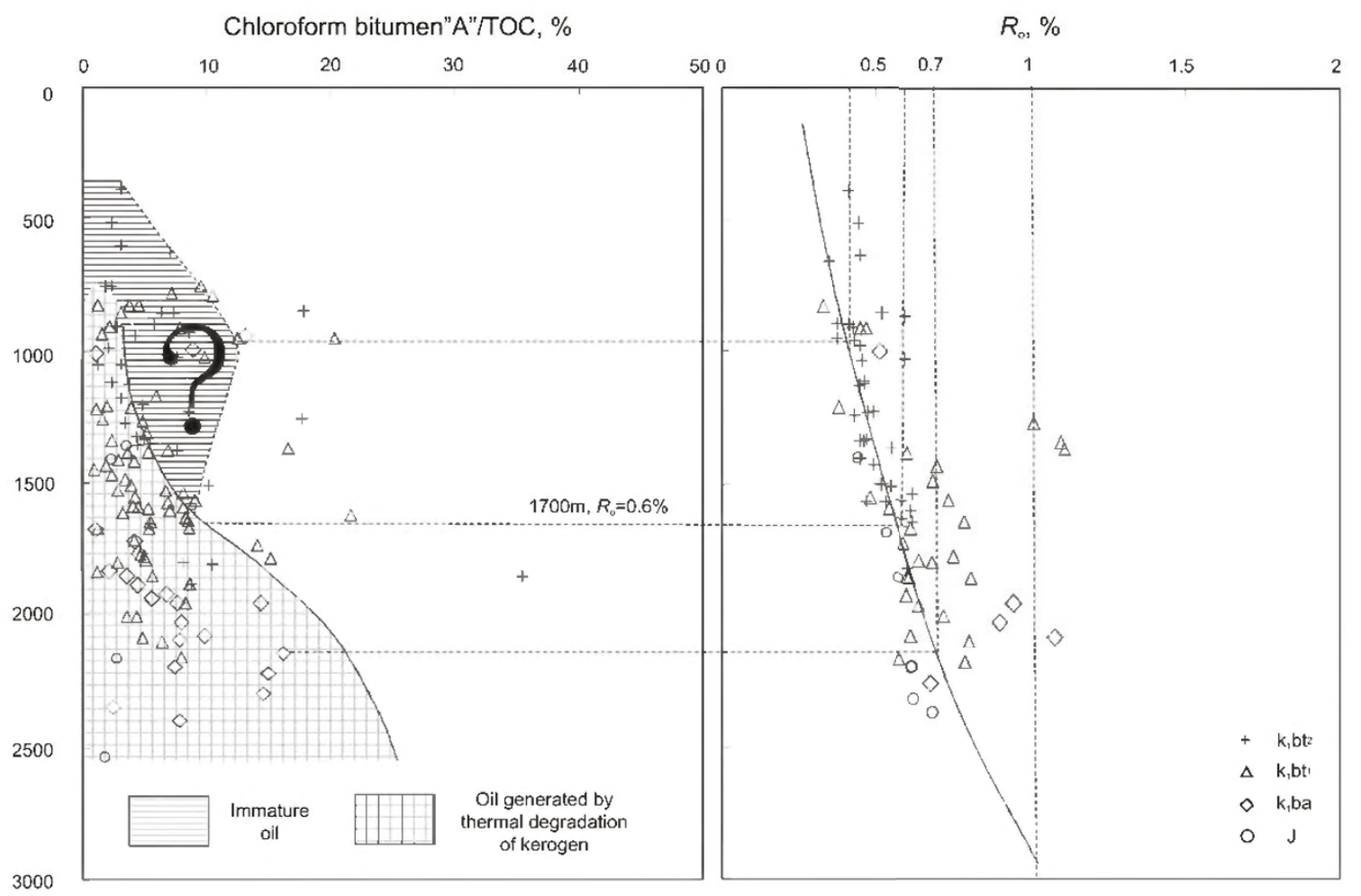

Fig. 6 Profiles of the hydrocarbon conversion ratio and $R_{v}$ in the Saihantala Sag (part of data source: Liu et al, 2009)

\section{Conclusions}

1) This study reported the detection of $\mathrm{C}_{31}$ to $\mathrm{C}_{35} 17 \alpha(\mathrm{H})$, $21 \beta(\mathrm{H})$ hopanes and hop-17(21)-enes occurring as doublets of $22 \mathrm{~S}$ and $22 \mathrm{R}$ isomers, neohop-(13,18)-ene and 30-norneohop$(13,18)$-ene in the Aershan Formation and in members 1 and 2 of the Tenggeer Formation in the Saihantala Sag.

2) The occurrence of hop-17(21)-enes indicates an anoxic environment. The biological source of hop-17(21)-enes may be bacteria. Comparable distributions of hopanes and hop- 17(21)-enes illustrate that hopanes may be the hydrogenation product of hop-17(21)-enes during diagenesis. Hop-17(21)enes are a direct indicator of immature to low-maturity stage sediments.

3) The sediments that correspond to the occurrence of hop17(21)-enes have a high hydrocarbon conversion ratio, high organic matter abundance and a biological source consisting of algae and bacteria. These indicate that the Saihantala Sag has the potential to generate immature oil, and thereby broaden the domain of oil exploration in the Erlian Basin. 


\section{Acknowledgements}

This work was supported by the National Science and Technology Major Project of China (2008ZX05018-002). The authors would like to thank Associate Professor Wang C.J. and Dr. Cui J.W. for helpful discussion and suggestions. We thank the two anonymous referees for their useful comments and suggestions.

\section{References}

Bechtel A, Markic M, Sachsenhofer R F, et al. Paleoenvironment of the upper Oligocene Trbovlje coal seam (Slovenia). International Journal of Coal Geology. 2004. 57(1): 23-48

Bechtel A, Widera M, Sachsenhofer R F, et al. Biomarker and stable carbon isotope systematics of fossil wood from the second Lusatian lignite seam of the Lubstow deposit (Poland). Organic Geochemistry. 2007. 38(11): 1850-1864

Bechtel A, Sachsenhofer R F, Kolcon I, et al. Organic geochemistry of the Lower Miocene Oberdorf lignite (Styrian Basin, Austria): Its relation to petrography, palynology and the palaeoenvironment. International Journal of Coal Geology. 2002. 51(1): 31-57

Boon J J, Hines H, Burlingame A L, et al. Organic geochemical studies of Solar Lake laminated cyanobacterial mats. In Advances in Organic Geochemistry 1981. Bjorùy M et al. (eds.) 1983. 207-227

Bottari F, Marsili A, Morelli I, et al. Aliphatic and triterpenoid hydrocarbons from ferns. Phytochem. 1972. 11(8): 2519-2523

De las Heras F X C, Grimalt J O, Lopez J F, et al. Free and sulphurized hopanoids and highly branched isoprenoids in immature lacustrine oil shales. Organic Geochemistry. 1997. 27(1/2): 41-64

Ensminger A, Albrecht P, Ourisson G, et al. Evolution of polycyclic alkanes under the effect of burial (Early Toarcian shales, Paris Basin). In: Campos R, Goni J. (Eds.), Advances in Organic Geochemistry 1975. Enadimsa, Madrid, 1977. 45-52

Farrimond P and Telnes N. Three series of rearranged hopanes in Toarcian sediments (northern Italy). Organic Geochemistry. 1996. 25(3/4): 165-177

Huang D F, Zhang D J, Wang P R, et al. Generation mechanism and accumulation conditions of immature oil in China. Beijing: Petroleum Industry Press. 2003 (in Chinese)

Kohnen M E L, Sinninghe Damste J S, ten Haven H L, et al. Identification and geochemical significance of cyclic di- and trisulphides with linear and acyclic isoprenoid carbon skeletons in immature sediments. Geochimica et Cosmochimica Acta. 1991. 55(12): 3685-3695

Liu Z, Zhang Z H, Xie Q B, et al. The oil geological character and resource prospect evaluation of new strata in Erlian basin. Huabei Oilfield Company of PetroChina, China University of Petroleum (Beijing). 2009 (in Chinese)
Ma L Q. Sequence Stratigraphy Research and Stratigraphic/Lithologic Reservoirs Prediction on Lower Cretaceous in A Nan-Abei Sag, Erlian Basin, China. Doctor Dissertations. Zhejiang University. 2005. 14-17 (in Chinese)

Moldowan J M and McCaffrey M A. A novel hydrocarbon degradation pathway revealed by hopane demethylation in a petroleum reservoir. Geochimica et Cosmochimica Acta. 1995. 59(9): 1891-1894

Ourisson G, Albrecht P and Rohmer M. The microbial origin of fossil fuels. Sci. Am. 1984. 251: 44-51

Palmer S E and Zumberge J E. Organic geochemistry of upper Miocene evaporite deposits in the Sicilian basin, Sicily. In: Brooks J. (ed.), Organic Maturation studies and Fossil Fuel Exploration, London: Academic Press. 1981. 393-426

Peters K E and Moldowan J M. The Biomarker Guide. Interpreting Molecular Fossils in Petroleum and Ancient Sediments. Prentice Hall, Englewood Cliffs, New Jersey, 1993. 363

Schwark L, Vliex M and Schaeffer P. Geochemical characterization of Malm Zeta laminated carbonates from the Franconian Alb, SWGermany (II). Organic Geochemistry. 1998. 29(8): 921- 952

Ten Haven H L, De Leeuw J W and Schenk P A. Organic geochemical studies of a Messinian evaporitic basin, northern Apennines (Italy). I: Hydrocarbon biomarkers for a hypersaline environment. Geochimica et Cosmochimica Acta. 1985. 49(10): 2181-2191

Volkman J K, Allen D I, Stevenson P L, et al. Bacterial and algal hydrocarbons from a saline Antarctic lake, Ace Lake. Organic Geochemistry. 1986. 10(4/6): 671-681

Wakeham S G. Algal and bacterial hydrocarbons in particulate material and interfacial sediment of the Cariaco Trench. Geochimica et Cosmochimica Acta. 1990. 54(5): 1325-1336

Wang D X, Zeng Q L and Ai X M. Hydrocarbon rock evaluation of the Dubei sag in the Saihantala depression. Journal of Oil and Gas Technology. 2007. 29(3): 185-187

Wang T G, Zhong N N, Hou D J, et al. Early oil generation mechanism of biological lipoid in a continental facies lake basin. Science in China (Series D: Earth Sciences). 1996. 26(6): 518-524 (in Chinese)

Wang T G, Zhong N N, Hou D J, et al. Generation mechanism and distribution of low maturity oil. Beijing: Petroleum Industry Press. 1995 (in Chinese)

Zhang L Y and Zhang C R. The Generation Mechanism and Accumulation System of Low Maturity Oil-a Case of South Slope of Niuzhuang Sag in Jiyang Downwarping Region. Beijing: Geology Press. 1999. 51-54 (in Chinese)

Zhao C L, Zhu Y H, Ji H C, et al. Reservoir Sedimentology of the Erlian Basin. Beijing: Petroleum Industry Press. 1996 (in Chinese)

Zhao Q M, Yang D Q, Jiang J G, et al. Organic geochemistry and depositional environment research of lower tertiary salt lake facies in the Wuyang and Xiangcheng sags. Acta Sedimentologica Sinica. 2003. 21(2): 334-339 (in Chinese)

(Edited by Zhu Xiuqin) 